\title{
In vivo polyploidy induction of Phalaenopsis amabilis in a bubble bioreactor system using colchicine
}

\author{
Mohsen Mohammadi ${ }^{1}$ (D), Behzad Kaviani ${ }^{*}$ (D), Shahram Sedaghathoor ${ }^{1} \mathbb{C}$
}

${ }^{1}$ Department of Horticultural Science, Rasht Branch, Islamic Azad University, Rasht, Iran

\begin{abstract}
Phalaenopsis amabilis Blume var. grandiflora Bateman is economically important as cut and pot flower. Polyploidy is considered as a valuable tool in improvement and evolution of ornamental plants. Protocorm-like bodies (PLBs) of P. amabilis were cultured on Murashige and Skoog medium containing $0.20 \mathrm{mg} \mathrm{L}^{-1}$ IBA together with $2.00 \mathrm{mg} \mathrm{L}^{-1} \mathrm{KIN}$ and $1.00 \mathrm{~g} \mathrm{~L}^{-1}$ activated charcoal and grown for a period of five months. Fully-developed plantlets from in vitro grown PLBs were immersed in a bubble reactor filled with half-strength Hoagland solution containing the antimitotic agent colchicine $(0.05 \%, 0.10 \%$ and $0.15 \%$, w/v) for $72 \mathrm{~h}$ with a few drops $(1 \mathrm{~mL}$ of $0.1 \%)$ of octylphenoxypolyethoxyethanol or Nonidet (P-40) as a surfactant. Plantlets were aerated to prevent hypoxia. Colchicine-treated and untreated plantlets were transferred to pots for a period of 60 days. Tetraploidy was successfully induced by $0.15 \%$ colchicine. Polyploidy levels were firstly detected using flow cytometry and then confirmed by cytological and morphological observations. The chromosome number was $2 n=2 x=38$ in diploids and $2 n=4 x=76$ in tetraploid. Incubation of plantlets in liquid medium containing $0.15 \%$ colchicine induced the maximum recovered tetraploids with minimum frequency of survival $(50 \%)$. The tetraploid plants were more compact and exhibited round and thick leaves with darker green color than diploids. Stomata size in tetraploids were larger with less density than diploids. Chloroplast number in guard cells of tetraploids was about two times more than that of control. These results indicate that induction of tetraploids are a reliable and powerful tool for generation of novel phenotypes with ornamental and horticultural value for genetic improvement and breeding. Produced tetraploids in current study have potential in the ornamental/floriculture trade.
\end{abstract}

Keywords: antimitotic agents, chromosome set doubling, orchids, ornamentals breeding, tetraploid.

\section{Resumo}

Indução de poliploidia in vivo de Phalaenopsis amabilis em sistema de biorreator de bolha usando colchicina Phalaenopsis amabilis Blume var. grandiflora Bateman é economicamente importante como flor cortada e em vaso. A poliploidia é considerada ferramenta valiosa no melhoramento e evolução das plantas ornamentais. Corpos semelhantes a protocórmio (PLBs) de P. amabilis foram cultivados em meio Murashige e Skoog contendo 0,20 $\mathrm{mg} \mathrm{L}^{-1}$ de IBA junto com 2,00 $\mathrm{mg} \mathrm{L}^{-1} \mathrm{KIN} \mathrm{e}^{1,00 \mathrm{~g}}$ $\mathrm{L}^{-1}$ de carvão ativado e cultivados por um período de cinco meses. Plântulas totalmente desenvolvidas de PLBs cultivadas in vitro foram imersas em um reator de bolha preenchido com solução de Hoagland meia-força contendo o agente antimitótico colchicina $\left(0,05 \%, 0,10 \%\right.$ e $\left.0,15 \% \mathrm{p} \mathrm{v}^{-1}\right)$ por $72 \mathrm{~h}$ com algumas gotas $(1 \mathrm{~mL}$ de $0,1 \%)$ de octilfenoxipolietoxietanol ou Nonidet (P-40) como um surfactante. As plântulas foram aeradas para prevenir a hipóxia. As plântulas tratadas e não tratadas com colchicina foram transferidas para vasos por um período de 60 dias. A tetraploidia foi induzida com sucesso pela colchicina $0,15 \%$. Os níveis de poliploidia foram detectados primeiramente por citometria de fluxo e depois confirmados por observações citológicas e morfológicas. O número de cromossomos era $2 n=2 x=38$ em diploides e $2 n=4 x=76$ em tetraploide. A incubação de mudas em meio líquido contendo $0,15 \%$ de colchicina induziu o máximo de tetraplóides recuperados com frequência mínima de sobrevivência $(50 \%)$. As plantas tetraplóides eram mais compactas e exibiam folhas arredondadas e grossas com coloração verde mais escura que as diplóides. O tamanho dos estômatos nos tetraploides foi maior com menos densidade do que nos diploides. O número de cloroplastos nas células-guarda dos tetraplóides era cerca de duas vezes mais do que no controle. Esses resultados indicam que a indução de tetraplóides é uma ferramenta confiável e poderosa para a geração de novos fenótipos com valor ornamental e hortícola para melhoramento genético. Os tetraplóides produzidos no presente estudo têm potencial no comércio ornamental e floricultura. Palavras-chave: agentes antimitóticos, duplicação de cromossômios, orquídeas, melhoramento de ornamentais, tetraploide.

*Corresponding author: b.kaviani@yahoo.com, kaviani@iaurasht.ac.ir 


\section{Introduction}

The genus Phalaenopsis belongs to the orchid family which comprises approximately 60 species native to tropical and subtropical Asia (Chen and Tang, 2018). Phalaenopsis has a high horticultural value as potted plants or cut flowers and is widely cultivated in greenhouses (Chuang et al., 2018). Because of the great diversity in plant type and flower color, Phalaenopsis species is one of the most popular orchids in the world market (Chen and Tang, 2018). Phalaenopsis amabilis Blume, commonly known as the moon or moth orchid is native to the East Indies and Australia, and widely cultivated as a decorative houseplant. The basic chromosome number of this group of orchids is $2 n=2 x=38$.

Most of the commercial varieties and hybrids of Phalaenopsis are tetraploids $(2 \mathrm{n}=4 \mathrm{x}=76)$, while the wild species are diploid. Around one-fourth of 63 species of the genus Phalaenopsis have been popularly used for the breeding of commercial hybrids. One of the most important problems is chromosome abnormalities and the occurrence of sterility after hybridization between tetraploid varieties and diploid species (Chuang et al., 2018). Therefore, there is a need to transform diploid species to tetraploid for development of new commercial varieties for the markets (Chen and Tang, 2018). New phenotypes produced through tetraploid induction have proper potential in the ornamental/floriculture trade. Tetraploids play an important role in variety improvement of Phalaenopsis orchids due to the advantages of large flower size and other characteristics (Chen and Tang, 2018). Polyploidy plays an important role in the breeding of many horticultural plants particularly orchids (Sattler et al., 2016; Chung et al., 2017; Pham et al., 2019). Polyploidization has the most important role in the hybridization, improvement and production of premium plants and varieties in the orchid floriculture industry (Miguel and Leonhardt, 2011; Azmi et al., 2016; Huy et al., 2019; Zakizadeh et al., 2020). Polyploidization of plants occurs in nature but it is a slow and gradual process. Polyploidization can be induced in a shorter period by using colchicine and other antimitotic agents that interferes with mitosis of cells (Eng and Ho, 2019). Polyploid plants exhibit vigorous growth with bigger organs, better quality and better resistance to biotic and abiotic stresses (Shi et al., 2016; He et al., 2016; Corneillie et al., 2018; Huy et al., 2019; Zakizadeh et al., 2020). Success of polyploidy induction depends upon the antimitotic agents' application method and concentration and exposure time duration, plant part (explant) used, species and cultivar type, concentration and exposure time duration. The efficiency of polyploidy induction system also depends on the advancement of propagation techniques of the species which consist of in vitro, ex vitro and in vivo systems (Eng and Ho, 2019).

Polyploidy is usually achieved by several antimitotic agents such as colchicine and oryzalin that inhibit mitosis, resulting in chromosome doubling. Colchicine was used successfully to produce polyploid plants in several species of Phalaenopsis (Griesbach, 1981) as well as in other orchids (Huy et al., 2019; Zakizadeh et al., 2020). The concentration and exposure time duration of colchicine for polyploidy induction is species-specific, the commonly used concentration of colchicine is between $0.01 \%$ and $1.00 \%$ (Huy et al., 2019).

Various plant parts such as apical meristem, flower bud, root tip and particularly seed can be used to induce polyploidy. In orchids, the most widely applied plant parts to induce polyploidy are protocorms and PLBs (Miguel and Leonhardt, 2011; Zakizadeh et al., 2020). Protocorm is a small tuber-like body formed by germinating orchid seed. It has the potential to develop into a fully grown orchid plant. PLBs are structures similar to protocorms but are formed by tissue explants and/or callus in vitro.

Traditionally, identification of polyploidy was carried out by chromosome counting (karyotype) using microscopy. This method is laborious and requires high skills (Chen and Tang, 2018). However, identification of polyploidy by chromosome counting may be useful for confirmation of other techniques like flow cytometry (FCM). Due to the advancement of new technologies, FCM has become a popular technique to determine the nuclear DNA content (Miguel and Leonhardt, 2011). FCM is an efficient and accurate method for genome size determination and ploidy identification (Eng and Ho, 2019; Hu et al., 2021). Genome sizes and fluorescence ratios of 50 species of Phalaenopsis were determined by FCM (Chen et al., 2014). Nevertheless, in order to confirm the data obtained by FCM, it is better to apply some morphological, anatomical and cytological parameters particularly stomata characteristics. Polyploidy levels can be precisely identified using a combination of these various methods. Authors recommend the use of morphological parameters, especially stomatal, to complement the ploidy analysis

Several studies were done on the induction of polyploidy in orchids. Most of these studies were carried out using colchicine in vitro on PLBs and protocorms. Some of the most important orchid's genera that were polyploidized using colchicine are: Phalaenopsis (Griesbach, 1981), Paphiopedilum (Huy et al., 2019), Dendrobium (Sarathum et al., 2010; Yenchon and Te-chato, 2014; Vichiato et al., 2014; Choopeng et al., 2019; Zakizadeh et al., 2020) and Cymbidium (Hwang et al., 2015). In vitro polyploid induction in orchids has been reported. However, few studies have been conducted on in vivo induction of polyploidy in orchids. Here, we present the first report of the successful induction of tetraploid plants of Phalaenopsis amabilis Blume var. grandiflora Bateman, through the in vivo application of colchicine in a bubble reactor using whole plantlets grown in vitro.

\section{Materials and Methods}

\section{Plant material}

PLBs of $P$. amabilis var. grandiflora Bateman were cultured on MS (Murashige and Skoog, 1962) medium containing $0.20 \mathrm{mg} \mathrm{L}^{-1} \mathrm{IBA}$ along with $2.00 \mathrm{mg} \mathrm{L}^{-1} \mathrm{KIN}$ and $1.00 \mathrm{~g} \mathrm{~L}^{-1}$ activated charcoal and grown for a period of five months. Five-month-old plantlets of $P$. amabilis produced from PLBs in in vitro condition were utilized as 
materials in this study. These plantlets lacked the minimum root to start the experiments. Therefore, the plantlets were rooted in a humid cultivation bed for 2 weeks followed by 3 days' dryness cycles per week. This step lasted 2 months.

\section{Colchicine treatment of whole plantlets}

Seven-month-old fully developed plantlets were plunged in a $500 \mathrm{~mL}$ bubble reactor filled with $1 / 2$ Hoagland solution containing colchicine $(0.05 \%, 0.10 \%$ and $0.15 \%)$ for $72 \mathrm{~h}$. Five plantlets per treatment were employed. These plantlets had $1 \mathrm{~cm}$ long and included 1 leaf. A few drops (1 mL of $0.1 \%$ ) of octylphenoxypolyethoxyethanol or Nonidet (P-40) was used as a surfactant.

\section{Cultivation condition of plantlets}

Following the treatment period $(72 \mathrm{~h})$, all treated and untreated (control) plantlets were washed completely with sterilized distilled water for $5 \mathrm{~min}$. Washed plantlets were then cultured in barks $(9 \mathrm{~mm})$ sterilized with water vapor $\left(100{ }^{\circ} \mathrm{C}\right)$ and cooled to room temperature. Size 15 clay pots ( 5 pots per treatment) were used as cultivation vessels and 5 plantlets were cultivated per pots. Plant protection against fungal agents was performed using ROVRAL$\mathrm{TS}^{\circledR}$ (iprodione $35 \%+$ carbendazim $17.5 \%$ ) solution. To prepare this fungicide, $1 \mathrm{~g}$ of iprodione + carbendazim mixture was dissolved in $1000 \mathrm{~mL}$ water and used as an irrigation solution.

\section{Flow cytometry}

Flow cytometry was used for detection of ploidy levels. The ploidy level of plantlets was determined using a BD FACSCalibur ${ }^{\mathrm{TM}}$ cell analyzer (BD Science, USA). Approximately, $0.02 \mathrm{~g}$ of fresh leaves, bulb and root of treated and untreated plantlets were homogenized (chopped with a sharp razor blade) in a $50 \mathrm{~mm}$ disposable Petri dish placed on ice containing nuclei extraction buffer, LB01. Three plantlets per treatment were analyzed. Chopping process was performed for $2.5 \mathrm{~min}$ and 5 hit per second. The extracts were passed through a $100 \mu \mathrm{m}$ cell strainer (to remove solid remains of the tissues) and then filtered through a $45 \mu \mathrm{m}$ nylon mesh filter to prevent clogging of cell analyzer's nozzle, and collected in a new micro-tube. Prior to injection Ribonuclease A (RNAase A) and Propidium Iodide (PI), both were added to final concentration of $50 \mu \mathrm{g} \mathrm{mL}^{-1}$ to obtain nuclei suspension and kept for at least $5 \mathrm{~min}$ on ice in a dark place. For absolute genome size determination, $200 \mu \mathrm{L}$ from $50 \mu \mathrm{g} \mathrm{mL}^{-1}$ stock solution of PI, a fluorescent intercalating agent or a DNAbinding dye, was used to stain nuclei. Ploidy levels were determined from the mean peak fluorescence of samples and the reference according to Doležel and Bartos (2005).

\section{Morphological and cytological measurements}

Plantlets length was measured by a ruler. Leaves width was measured by a scanner. Scanned leaves were analyzed using Digimizer image analysis software (https://www. digimizer.com). Plantlet length was calculated from last leaf tip to the root tip. Leaf width was calculated from the widest section of each leaf. Leaf samples were taken from the control (water-treated) plantlets and from the putative tetraploid plantlets which were detected using FCM analysis. The samples were taken at approximately the same point on each plant. Plantlets included 3 leaves at this stage. Middle leaf of each plantlet was used for cytological measurements. Measurement of stomatal characteristics were adopted from Manzoor et al. (2018). A thin layer of epidermis tissues was removed from the abaxial surface of the leaves by a sharp razor and stained by toluidine blue on slides along with a drop of water. The $20 \mathrm{mM} \mathrm{KCl}$ was added to water due to the better conditions of stoma pore. The slides were analyzed for stomatal size and number and chloroplast number under a light microscope (Standard 4, Zeiss, Germany). Three slides were prepared for each plantlet and the length and width of 10 stomata and their chloroplast number on each slide were measured using image analyzer digitizer software.

\section{Statistics}

The experiments were conducted in completely randomized design (CRD). The 4 treatments were applied, each treatment had 3 replications and each replication had 20 individuals. Therefore, in these experiments, a total of 240 plantlets were used. All the statistical analyses were done by using Microsoft Excel 365 and SAS v $9.4^{\circledR}$. The analysis of variance (ANOVA) procedure for the experiments were used to test for significant effect of treatments, followed by contrast and LSD test for comparisons of different means of different treatments.

\section{Results}

\section{Generation of polyploidy}

In vitro-grown PLBs were exposed to the concentrations of $0.05 \%, 0.10 \%$ and $0.15 \%\left(\mathrm{w} \mathrm{v}^{-1}\right)$ colchicine for $72 \mathrm{~h}$. Among these three treatments, $0.15 \%$ was the most effective for tetraploid induction. Survival percentage was decreased in line with increasing the colchicine concentration (Table 1). 
Table 1. Effect of colchicine treatments on different morphological and anatomical parameters of P. amabilis var. grandiflora Bateman

\begin{tabular}{|c|c|c|c|c|c|c|c|c|c|}
\hline $\begin{array}{c}\text { Colchicine } \\
(\%)\end{array}$ & $\begin{array}{c}\text { Plantlet } \\
\text { length } \\
\text { (cm) }\end{array}$ & $\begin{array}{c}\text { Leaf } \\
\text { width } \\
(\mathrm{cm})\end{array}$ & $\begin{array}{c}\text { Leaf } \\
\text { number }\end{array}$ & $\begin{array}{c}\text { Root } \\
\text { number }\end{array}$ & $\begin{array}{c}\text { Guard } \\
\text { cell length } \\
(\mu \mathrm{m})\end{array}$ & $\begin{array}{c}\text { Guard } \\
\text { cell width } \\
(\mu \mathrm{m})\end{array}$ & $\begin{array}{l}\text { Stomata } \\
\text { number }\end{array}$ & $\begin{array}{c}\text { Chloroplast } \\
\text { number }\end{array}$ & $\begin{array}{c}\text { Survival } \\
(\%)\end{array}$ \\
\hline 0.00 & $\begin{array}{c}4.20 \pm \\
0.08 \mathrm{a}\end{array}$ & $\begin{array}{l}1.20 \pm \\
0.01 \mathrm{~d}\end{array}$ & $\begin{array}{c}2.12 \pm \\
0.09 \mathrm{c}\end{array}$ & $\begin{array}{c}5.60 \pm \\
0.60 \mathrm{a}\end{array}$ & $\begin{array}{c}33.50 \pm \\
2.50 \mathrm{c}\end{array}$ & $\begin{array}{c}42.70 \pm \\
4.00 \mathrm{c}\end{array}$ & $\begin{array}{c}4.00 \pm \\
0.30 \mathrm{a}\end{array}$ & $\begin{array}{c}40.68 \pm \\
9.00 \mathrm{~d}\end{array}$ & $\begin{array}{c}85.00 \pm \\
4.63 \mathrm{a}\end{array}$ \\
\hline 0.05 & $\begin{array}{l}3.70 \pm \\
0.06 \mathrm{ab}\end{array}$ & $\begin{array}{l}1.87 \pm \\
0.30 \mathrm{c}\end{array}$ & $\begin{array}{l}3.11 \pm \\
0.08 b\end{array}$ & $\begin{array}{l}4.70 \pm \\
0.34 b\end{array}$ & $\begin{array}{l}35.32 \pm \\
3.40 \mathrm{~cd}\end{array}$ & $\begin{array}{c}43.50 \pm \\
3.30 \mathrm{c}\end{array}$ & $\begin{array}{l}3.50 \pm \\
0.57 \mathrm{~b}\end{array}$ & $\begin{array}{c}50.41 \pm \\
8.00 \mathrm{c}\end{array}$ & $\begin{array}{c}80.00 \pm \\
2.89 b\end{array}$ \\
\hline 0.10 & $\begin{array}{c}2.60 \pm \\
0.04 \mathrm{c}\end{array}$ & $\begin{array}{l}2.51 \pm \\
0.12 \mathrm{ab}\end{array}$ & $\begin{array}{c}3.08 \pm \\
0.04 b\end{array}$ & $\begin{array}{c}3.90 \pm \\
0.70 \mathrm{c}\end{array}$ & $\begin{array}{c}39.10 \pm \\
4.40 \mathrm{~b}\end{array}$ & $\begin{array}{c}56.70 \pm \\
6.60 \mathrm{~b}\end{array}$ & $\begin{array}{c}2.30 \pm \\
0.79 \mathrm{c}\end{array}$ & $\begin{array}{c}69.30 \pm \\
4.04 \mathrm{~b}\end{array}$ & $\begin{array}{c}71.00 \pm \\
3.76 \mathrm{c}\end{array}$ \\
\hline 0.15 & $\begin{array}{c}2.20 \pm \\
0.01 \mathrm{c}\end{array}$ & $\begin{array}{c}2.81 \pm \\
0.02 \mathrm{a}\end{array}$ & $\begin{array}{c}4.08 \pm \\
0.03 a\end{array}$ & $\begin{array}{l}3.10 \pm \\
0.20 \mathrm{~d}\end{array}$ & $\begin{array}{c}48.60 \pm \\
1.20 \mathrm{a}\end{array}$ & $\begin{array}{c}61.30 \pm \\
2.70 \mathrm{a}\end{array}$ & $\begin{array}{r}2.00 \pm \\
0.88 \mathrm{~d}\end{array}$ & $\begin{array}{c}78.90 \pm \\
2.00 \mathrm{a}\end{array}$ & $\begin{array}{c}50.00 \pm \\
2.07 \mathrm{~d}\end{array}$ \\
\hline
\end{tabular}

Means with different letters on the same column are significantly different $(p<0.05)$ based on LSD contrast test

Therefore, maximum mortality rate $(50 \%)$ was observed with $0.15 \%\left(\mathrm{w} \mathrm{v}^{-1}\right)$ colchicine. The highest survival rate was found in untreated plantlets. Root formation was low in tetraploid plantlets. Survived plantlets from all treatments were grown in pots and evaluated for the presence of polyploidy through measurement of different parameters after 60 days. Tetraploid induction has successfully been done with $P$. amabilis, an economically-useful orchid, by colchicine (Figure 1). Polyploidy was not occurred during application of the $0.05 \%$ colchicine (Figure 1).
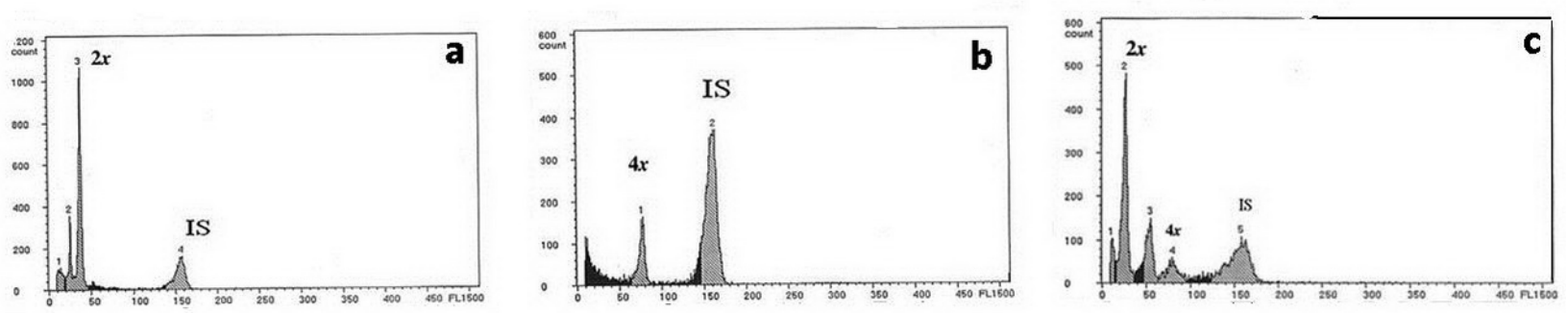

Figure 1. Representative flow cytometry histograms of the diploid (a), tetraploid (b) and mixoploid (c)

P. amabilis var. grandiflora Bateman treated by different concentrations of colchicine for $72 \mathrm{~h}$. Axis X: Fluorescence intensity; Axis Y: Number of nuclei; $2 \times$ : two chromosome set; $4 \times$ : four chromosome set; IS: isotype.

\section{Flow cytometric analysis}

Histograms obtained by FCM showed diploids, tetraploids and mixoploids. Mixoploids comprised diploid and tetraploid (Figure 1). Non-colchicine treated $P$. amabilis showed DNA ploidy levels equivalent to diploids (Figure 1A). Ploidy levels were determined for other treated plantlets through comparison with diploids. Produced diploid, tetraploid and mixoploid were 85, 65 and $55 \%$, respectively. FCM histogram (Figure 1B) revealed two clear peaks of nuclear DNA content which indicate the plantlets were tetraploid $(2 \mathrm{n}=4 \mathrm{x})$. FCM analysis also showed mixoploidy (2n:4n) (Figure 1C). The mixoploid plants were found in all three concentrations of colchicine, while the tetraploid plants were observed in 0.10 and $0.15 \%$ concentrations (Figure 1). The induction of polyploids was negatively correlated with the survival rate (Table 1). Stomata features (Figure 2), and leaf size (Figure 3) were measured to corroborate FCM analysis.

\section{Morphological and stomata characteristics}

Morphological and cytological observations were utilized to confirm the results obtained by FCM. The presentation and execution of alternative methodologies for verifying ploidy is interesting. Leaves parameters of diploids and tetraploids were significantly different in the items of leaf width, leaf number, length and width of stomata guard cells, stomata number, and number of chloroplasts per stomata guard cells (Tables 1 and 2). 

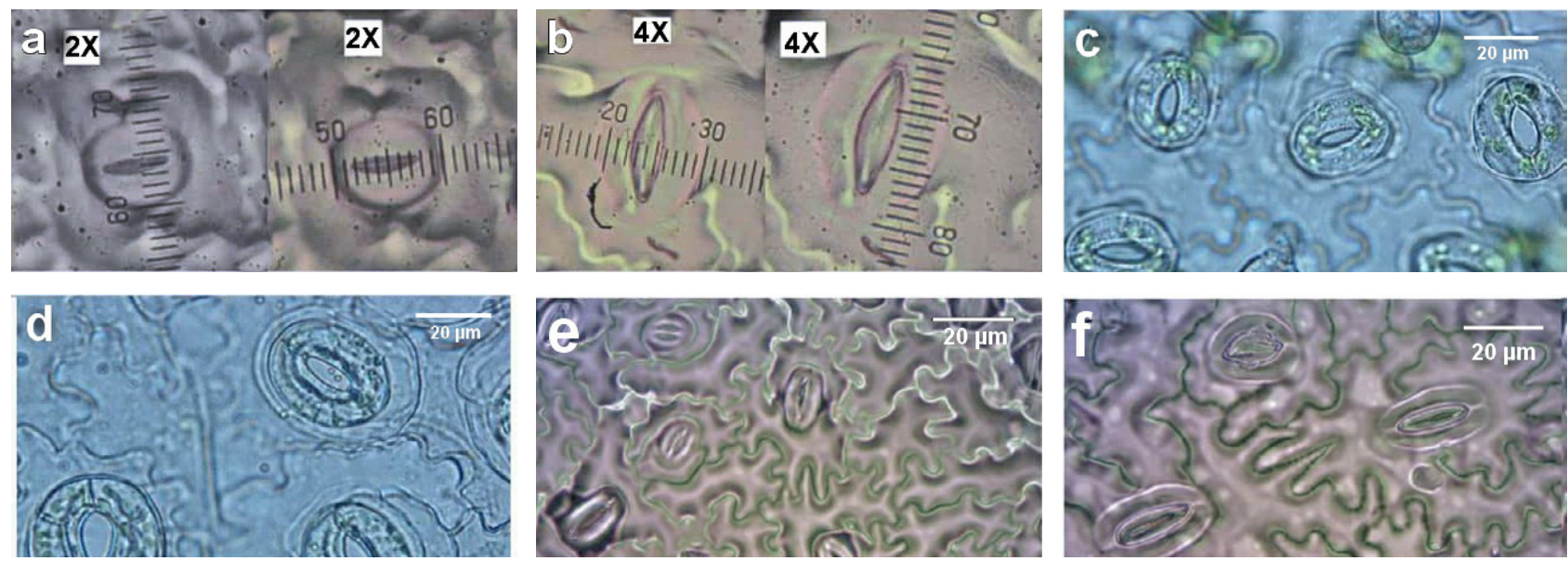

Figure 2. Stomata size (length and width) in diploid (a), and tetraploid (b); general appearance of chloroplasts and plant guard cells from diploids (c) and tetraploids (d); and stomata density in diploid (e) and tetraploid (f) of leaves of $P$. amabilis var. grandiflora Bateman. Photographs were taken under a light microscope containing netted lens. Bar $=20 \mu \mathrm{m}$.

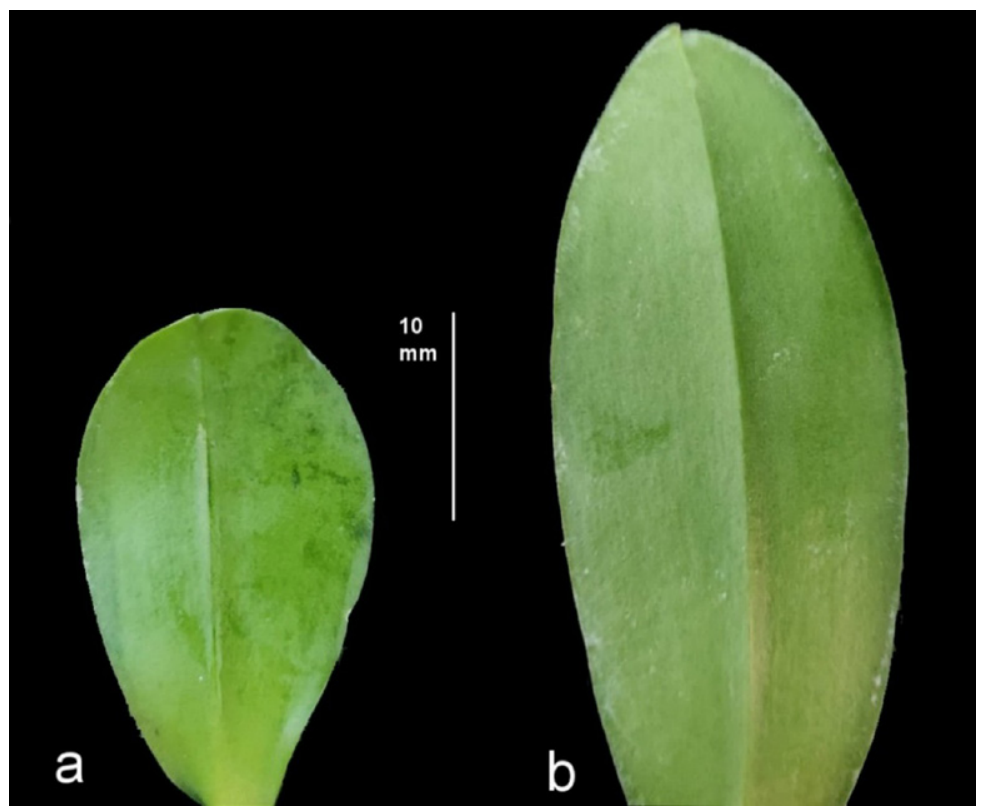

Figure 3. Measurement of leaf size in P. amabilis var. grandiflora Bateman. Length and width of diploid (a) and tetraploid (b) leaves.

Table 2. Comparison of morphological and anatomical parameters of diploid, tetraploid and mixoploid of P. amabilis var. grandiflora Bateman treated with colchicine

\begin{tabular}{|c|c|c|c|}
\hline Parameters & Diploids & Tetraploids & Mixoploids \\
\hline Plantlet length & $4.20 \pm 0.90 \mathrm{a}$ & $3.95 \pm 0.75 \mathrm{ab}$ & $2.89 \pm 0.67 \mathrm{c}$ \\
\hline Leaf width & $1.87 \pm 0.65 \mathrm{c}$ & $2.80 \pm 0.78 \mathrm{a}$ & $2.60 \pm 0.43 \mathrm{ab}$ \\
\hline Leaf number & $2.36 \pm 0.98 \mathrm{c}$ & $3.21 \pm 0.96 \mathrm{~b}$ & $3.82 \pm 0.88 \mathrm{a}$ \\
\hline Root number & $5.63 \pm 0.70 \mathrm{a}$ & $2.82 \pm 0.48 \mathrm{c}$ & $3.13 \pm 0.80 \mathrm{~b}$ \\
\hline Guard cell length & $33.61 \pm 6.55 \mathrm{c}$ & $48.72 \pm 5.97 \mathrm{a}$ & $45.51 \pm 8.90 \mathrm{~b}$ \\
\hline Guard cell width & $42.33 \pm 4.76 \mathrm{c}$ & $57.30 \pm 8.56 \mathrm{~b}$ & $61.51 \pm 10.10 \mathrm{a}$ \\
\hline Stomata number & $3.00 \pm 0.68 \mathrm{a}$ & $2.00 \pm 0.86 \mathrm{~b}$ & $1.00 \pm 0.53 \mathrm{c}$ \\
\hline Chloroplast number & $40.31 \pm 10.42 \mathrm{c}$ & $78.72 \pm 7.53 \mathrm{a}$ & $70.57 \pm 12.10 \mathrm{~b}$ \\
\hline Viability & $85.00 \pm 6.35 \mathrm{a}$ & $65.00 \pm 4.55 \mathrm{~b}$ & $55.00 \pm 3.78 \mathrm{c}$ \\
\hline
\end{tabular}

Means within each row with different letters are significantly different at the $\mathrm{p}<0.05$ level 
Tetraploid shoots had higher leaf width, guard cell length and chloroplasts number per stomata guard cell than diploids and mixoploids. Leaf number and guard cell width in tetraploid plantlets were higher than those of diploids plantlets but lower than mixoploids. Maximum plantlet length, root number and stomata number were obtained in diploid plantlets. On the other hand, maximum leaf number and guard cell width were obtained in mixoploids. Totally, the induced tetraploid plantlets by treatment with $0.15 \%$ colchicine were characterized by wider leaf width $(2.81 \mathrm{~cm})$ and stomata guard cell width $(61.30 \mu \mathrm{m})$, longer stomata guard cell length $(48.60 \mu \mathrm{m})$ and more chloroplast number in guard cells (78.90) and leaf number (4.08) compared with the diploid and mixoploid plants (Table 1, Figures 2 and 3). Colchicine had a marked influence on the growth of plantlets. The plantlets length decreased with the increase in colchicine concentration and the highest length was observed in diploid plantlets (Table 1). Tetraploid plantlets exhibited relatively round leaves with darker green color than diploids.

\section{Discussion}

Polyploidy plays an important role in breeding of orchids (Miguel and Leonhardt, 2011). Tetraploid P. amabilis Blume var. grandiflora Bateman with better quality was successfully obtained by colchicine. Colchicine as an antimitotic agent has been applied for the improvement of horticultural characteristics for a variety of species by polyploidy induction (Dhooghe et al., 2011; Silva et al., 2019). The effectiveness of colchicine application and polyploid induction depends on some factors especially type of explant, exposure time and concentration (Huy et al., 2019; Zakizadeh et al., 2020). Young tissues containing actively dividing cells are preferred to induce polyploidy (Huy et al., 2019). In current study, plantlets obtained from in vitro grown PLBs were suitable explant for colchicine treatment and polyploidy induction. Tetraploid plants were produced by plunging the plantlets in a bubble reactor containing $0.15 \%$ colchicine for $72 \mathrm{~h}$. In Dendrobium 'Sonia', plantlets with changed chromosome number were obtained at $0.05 \%-0.15 \%$ colchicine concentrations (tetraploid induction) (Zakizadeh et al., 2020). Some researchers used from protocorms and PLBs to obtain polyploidy in orchids (Griesbach, 1981; Miquel and Leonhardt, 2011; Yenchon and Te-chato, 2014; Chen and Tang, 2018; Zakizadeh et al., 2020). Explants must be exposed to antimitotic agents at levels and times high enough to saturate plant tissues and induce polyploidy. Optimum concentration of colchicine and exposure time are different for each species and variety, even within the same family of plants (Sarathum et al., 2010; Shala and Deng, 2018; Manzoor et al., 2018). Colchicine has been used at $0.05 \%-0.20 \%$ concentrations and 2-9 days for orchids (Yenchon and Te-chato, 2014; Vichiato et al., 2014; Huy et al., 2019; Zakizadeh et al., 2020). Atichart and Bunnag (2007) on Dendrobium secundum (B1.) Lindl. showed high frequencies of polyploidy in PLBs on culture media containing $0.05 \%$ and $0.04 \%$ colchicine both for a day. Four days' exposure time of the protocorms to $0.10 \%$ colchicine reduced survival percentage of Dendrobium draconis Rchb. f. (Bunnag and Hongthongkham, 2015). Colchicine with the dose of $0.15 \%$ for 3 days was the most efficient to induce tetraploids in Dendrobium 'Sonia' (Zakizadeh et al., 2020).

High concentrations of colchicine are associated with plant cell death due to the highly toxic effect of this antimitotic agent (Blasco et al., 2015). High mortality rate in orchids occurred through application of high concentrations of colchicine (Sarathum et al., 2008; Yenchon and Te-chato, 2014; Vichiato et al., 2014; Huy et al., 2019; Choopeng et al., 2019). Investigation on polyploid induction in Dendrobium nobile revealed that $0.10 \%$ colchicine for 4 days is suitable (Vichiato et al., 2014). Also, Yenchon and Te-chato (2014) reported that the maximum polyploid plants were induced with application of $0.20 \%$ colchicine for 2 days in PLBs of Dendrobium formosum. Treatment of colchicine at concentrations of $0.025 \%-0.10 \%$ for $3-21$ days produced tetraploids in Dendrobium scabrilingue L. (Sarathum et al., 2010). Three days' exposure of the protocorms to $0.05 \%$ colchicine was most effective in polyploid induction in Dendrobium draconis Rchb. f. (Bunnag and Hongthongkham, 2015). In general, the optimum colchicine concentration for polyploidy induction in orchids seems to be $0.01 \%-0.10 \%$, while the optimum exposure time strongly depends on the type of explant and the method applied for application (Sarathum et al., 2010). Most polyploid induction studies were carried out in in vitro conditions. Current study demonstrated that polyploid induction, including tetraploid and mixoploid plantlets, is feasible by treating in vivo $P$. amabilis whole plantlets with colchicine.

We have successfully used FCM to determine polyploidy in treated $P$. amabilis plantlets. Nevertheless, in order to confirm the data obtained by FCM, it is better to use some morphological and cytological parameters. Polyploidy levels can be precisely identified using a combination of various methods. FCM is a very well-established and effective technique for counting suspended particles and the combination of these two techniques can provide interesting results for verifying ploidy. In the present study, some morphological and cytological parameters, particularly stomata characteristics corroborated the difference in DNA content observed by FCM. Detection of polyploidy in Phalaenopsis (Griesbach, 1981), Cymbidium, Lycaste and Epidendrum hybrids (Aoyama, 2010), Dendrobium nobile (Vichiato et al., 2014), Dendrobium formosum (Yenchon and Te-chato, 2014) and Dendrobium, Epidendrum, Odontioda and Phalaenopsis (Miguel and Leonhardt, 2011) was carried out using morphological, anatomical and cytological characteristics. However, polyploidy detection by morphological or cytological investigations alone has some limitations (Chen et al., 2009; Dhooghe et al., 2011).

Stomata features (size and density) and the number of chloroplasts in guard cells as cytological parameters were also used to corroborated polyploidy. These are simple, fast, effective, and economical method to select polyploids from diploids (Dhooghe et al., 2011; Bagheri and Mansouri, 
2015; Huy et al., 2019). This method was applied to identify the genetic characteristics of Phalaenopsis, Cymbidium, Epidendrum, Dendrobium, and Odontioda (Chen et al., 2009; Miguel and Leonhardt, 2011; Zakizadeh et al., 2020). In the present study, the results obtained by measuring the stomata size were matched and corroborated the ploidy levels of treated and untreated plantlets observed by FCM. Several studies showed increase in the size of guard cell of orchids treated with colchicine compared to the untreated plants (Atichart and Bunnag, 2007; Chen et al., 2009; Miguel and Leonhardt, 2011; Huy et al., 2019; Choopeng et al., 2019). In our study, the number of chloroplasts in stomata cells was different between diploid and tetraploid plantlets.

Our study showed that the tetraploid plants were more compact and exhibited round and thick leaves with darker green color than diploids. Similar results were reported by Atichart and Bunnag (2007) in Dendrobium secundum (B1.) Lindl., Sarathum et al. (2010) in Dendrobium scabrilingue L. and Bunnag and Hongthongkham (2015) in Dendrobium draconis Rchb. f. The obtained polyploid plants had thicker and darker green leaves when compared to diploid plants. The decreased growth in tetraploid plantlets is due to the reduced rate of cell division that caused by colchicine. Based on current study, the length of the seedlings, as well as the number of roots and stomata decrease significantly. These parameters do not have much effect on orchids marketing. The most important qualitative parameters, in addition to flower characteristics, are leaf shape, number of leaves and leaf color. These parameters make commercial production of Phalaenopsis amabilis recommendable and interesting. Totally, our findings revealed that in vivo induction of tetraploids may be an important tool for generating novel phenotypes for breeding and genetic improvement of orchids, particularly by using protocorms and PLBs.

\section{Conclusions}

In conclusion, the most successful concentration of colchicine for inducing tetraploids was $0.15 \%$. Method presented in the present investigation may be interesting for breeding programs, even with high plant mortality, because the viable regenerated plantlets can be propagated. The presented technique is interesting as a starting point for future studies. Polyploidy plays an important role in improvement of orchids. Through the use of whole plantlets obtained from PLBs, current study has demonstrated an effective, simple and reliable protocol in the generation of Phalaenopsis amabilis Blume var. grandiflora Bateman tetraploid plantlets for future breeding purposes. These findings may be applied to further develop protocols for the in vivo polyploid induction of orchids with colchicine. This method would also be beneficial to orchid breeding programs particularly for the interspecific hybridization between varieties having different chromosome number. Tetraploids have potential in the ornamental/floriculture trade.

\section{Author Contribution}

MM: grew the seedlings and performed the experiments, BK: designed the experiments and wrote the manuscript, SS: designed the experiments and analyzed the data.

\section{References}

AOYAMA, M. Chromosome research for orchid breeding. Acta Horticulturae, v.878, n.13, p.125-132, 2010. https:// doi.org/10.17660/ActaHortic.2010.878.13.

ATICHART, P.; BUNNAG, S. Polyploid induction in Dendrobium secundum (B1.) Lindl.by in vitro techniques. Thai Journal of Agricultural Science, v.40, n.1-2, p.9195, 2007.

AZMI, T.K.K.; SUKMA, D.; AZIZ, S.A.; SYUKUR, M. Polyploidy induction of moth orchid (Phalaenopsis amabilis (L.) Blume) by colchicine treatment on pollinated flowers. The Journal of Agricultural Sciences, v.11, n.2, p.62-73, 2016.

BAGHERI, M.; MANSOURI, H. Effect of induced polyploidy on some biochemical parameters in Cannabis sativa L. Applied Biochemistry and Biotechnology, v.175, n.5, p.2366-2375, 2015.

BLASCO, M.; BADENES, M.L.; NAVAL, M.D.M. Colchicine-induced polyploidy in loquat (Eriobotrya japonica (Thunb.) Lindl.). Plant Cell, Tissue and Organ Culture, v.120, n.2, p.453-461, 2015. https://doi. org/10.1007/s11240-014-0612-3.

BUNNAG, S.; HONGTHONGKHAM, J. Polyploid induction of Dendrobium draconis Rchb. f. Acta Hortulturae, 2015. https://doi.org/10.17660/ ActaHortic.2015.1087.60.

CHEN, W.H.; KAO, Y.L.; TANG, C.Y. Variation of the genome size among Phalaenopsis species using DAPI fluorochrome and flow cytometry. Journal of Taiwan Society for Horticultural Science, v.60, p.115-123, 2014.

CHEN, W.H.; TANG, C.Y. A protocol for the induction of polyploids in Phalaenopsis orchids by in vitro method without using anti-microtubule agents. In: Lee, Y.I., Yeung, E.C.T. (eds). Orchid Propagation: from laboratories to greenhouse - methods and protocols. Totowa: Humana Press, 2018. p.317-330.

CHEN, W.H.; TANG, C.Y.; KAO, Y.L. Ploidy doubling by in vitro culture of excised protocorms or protocorm-like bodies in Phalaenopsis species. Plant Cell, Tissue and Organ Culture, v.98, n.2, p.229-238, 2009. https://doi. org/10.1007/s11240-009-9557-3. 
CHOOPENG, S.; TE-CHATO, S.; KHAWNIUM, T. Effect of colchicine on survival rate and ploidy level of hydrid between Dendrobium santana $\mathrm{x}$ D. friedericksianum orchid. International Journal of Agricultural Technology, v.15, n.2, p.249-260, 2019.

CHUANG, H.T.; HUANG, K.L.; HSU, S.T. Cut-column pollination method to overcome pollination barrier in Phalaenopsis. In: Lee, Y.I., Yeung, E.C.T. (eds). Orchid Propagation: from laboratories to greenhouse - methods and protocols. 2018. Totowa: Humana Press, 2018. p.241-256.

CHUNG, H.; SHI, H.; HUANG, B.; CHEN, J. Enhanced agronomic traits and medicinal constituents of autotetraploids in Anoectochilus formosanus Hayata, a top-grade medicinal orchid. Molecules, v.22, p.1-13, 2017. https://doi.org/10.3390/molecules22111907.

CORNEILLIE, S., DE STORME, N, VAN ACKER, R., FANGEL, J.U., DE BRUYNE, M., DE RYCKE, R.M., GEELEN, D., WILLATS, W.G.T., VANHOLME, B., BOERJAN, W.A. Polyploidy affects plant growth and alters cell wall composition. Plant Physiology, v.179, p.74-87, 2018.

DHOOGHE, E.; VAN LAERE, K.; EECJHAUT, T.; LEUS, L.; VAN HUYLENBROECK, J. Mitotic chromosome doubling of plant tissues in vitro. Plant Cell, Tissue and Organ Culture, v.104, n.3, p.359-373, 2011. https://doi. org/10.1007/s11240-010-9786-5.

DOLEŽEL, J.; BARTOS, J. Plant DNA flow cytometry and estimation of nuclear genome size. Annals of Botany, v.95, p.99-110, 2005.

ENG, W.H.; HO, W.S. Polyploidization using colchicine in horticultural plants: A review. Scientia Horticulturae, v.246, p.604-617, 2019. https://doi.org/10.1016/j.scientia. 2018.11.010.

GRIESBACH, R.J. Colchicine-induced polypoloidy in Phalaenopsis orchids. Plant Cell, Tissue and Organ Culture, v.1, n.1, p.103-107, 1981. https://doi.org/10.1007/ BF02318909.

HE, Y.; SUN, Y.; ZHENG, R.; AI, Y.; CAO, Z.; BAO, M. Induction of tetraploid male sterile Tagetes erecta by colchicine treatment and its application for interspecific hybridization. Horticultural Plant Journal, v.2, n.5, p.284-292, 2016.

HU, Y.; SUN, D.; HU, H.; ZUO, X.; XIA, T.; XIE, J. A comparative study on morphological and fruit quality traits of diploid and polyploid carambola (Averrhoa carambola L.) genotypes. Scientia Horticulturae, v.277, 109843. 2021. https://doi.org/10.1016/j.scientia. 2020.109843.
HUY, N.P.; TAM, D.T.T.; LUAN, V.O.; TUNG, H.T.; HIEN, V.T.; NGAN, H.T.M.; DUY, P.N.; NHUT, D.T. In vitro polyploid induction of Paphiopedilum villosum using colchicine. Scientia Horticulturae, v.252, p.283-290, 2019. https://doi.org/10.1016/j.scienta.2019.03.063.

HWANG, S.H.; KIM, M.S.; PARK, S.Y. Improvement of chromosome doubling efficiency in Cymbidium hybrids by colchicine and oryzalin treatment. Horticultural Science and Technology, v.33, n.6, p.900-910, 2015. https://doi. org/10.7235/hort.2015.15063.

MANZOOR, A.; AHMAD, T.; BASHIR, M.A.; BAIG, M.M.Q.; QURESH, A.A.; SHAH, M.K.N.; HAFIZ, I.A. Induction and identification of colchicine induced polyploidy in Gladiolus grandiflorus 'White Prosperity'. Folia Horticulturae, v.30, n.2, p.307-319, 2018.

MIGUEL, T.P.; LEONHARDT, K.W. In vitro polyploid induction of orchids using oryzalin. Scientia Horticulturae, v.130, n.1, p.314-319, 2011. https://doi.org/10.1016/j. scienta.2011.07.002.

MURASHIGE, T.; SKOOG, F. A revised medium for rapid growth and bioassays with tobacco tissue cultures. Physiology Plant v.15, p.473-479. 1962.

PHAM, P.K., LI, Y.X., GUO, H.R., ZENG, R.Z., XIE, L., ZHANG, Z.S. Changes in morphological characteristics, regeneration ability, and polysaccharide content in tetraploid Dendrobium officinale. HortScience, v.54, n.11, p.1879-1886, 2019.

SARATHUM, S.; HEGELE, M.; TANTIVIWAT, S.; NANAKORN, M. Effect of concentration and duration of colchicine treatment on polyploidy induction in Dendrobium scabrilingue L. European Journal of Horticultural Science, v.75, p.123-127, 2010. https://doi. org/10.2307/24126421.

SARATHUM, S.; NANAKORN, M.; TANTIVIWAT, S. Effect of concentration and duration of colchicine treatment on polyploidy induction in Dendrobium scabriligue Linld. in vitro. In 46. Kasetsart University Annual Conference, Bangkok, Thailand, 2008.

SATTLER, M.C.; CARVALHO, C.R.; CLARINDE, W.R. The polyploidy and its role in plant breeding. Planta, v.243, p.281-296, 2016.

SHALA, A.Y.; DENG, Z. Investigation of morphological and anatomical changes in Catharanthus roseus (L.) G. Don due to colchicine induced polyploidy. Scientific Journal of Flowers and Ornamental Plants, v.5, n.3, p.233-243, 2018. 
SHI, Q.; LIU, P.; LIU, M.; WANG, J.; ZHAO, J.; ZHAO, Z.; DAI, L. In vivo fast induction of homogeneous autopolyploids via callus in sour jujube (Ziziphus acidojujuba Cheng et Liu). Horticultural Plant Journal, v.2, n.3, p.147-153, 2016.

SILVA, A.J.; CARVALHO, C.R.; CLARINDO, W.R. Chromosome set doubling and ploidy stability in synthetic autoand allotetraploid of Eucalyptus: from in vitro condition to the field. Plant Cell, Tissue and Organ Culture, v.138, p.387-394, 2019.

VICHIATO, M.R.M.; VICHIATO, M.; PASQUAL, M.; RODRIGUES, F.A.; DE CASTRO, D.M. Morphological effects of induced polyploidy in Dendrobium nobile Lindl. (Orchidaceae). Crop Breeding and Applied Biotechnology, v.14, n.3, p.154-159, 2014. https://doi. org/10.1590/1984-70332014v14n3a23.
YENCHON, S.; TE-CHATO, S. Polyploidy induction of Dendrobium formosum by colchicine treatment in vitro. Acta Horticulturae, v.1025, n.12, p.81-88, 2014. https:// doi.org/10.17660/ActaHortic.2014.1025.12.

ZAKIZADEH, S., KAVIANI, B., HASHEMABADI, D. In vivo-induced polyploidy in Dendrobium 'Sonia' in a bubble bioreactor system using colchicine and oryzalin. Brazilian Journal of Botany, v.23, p.921-932, 2020. https://doi. org/10.1007/s40415-02000654-z. 